\title{
FAKTY I LEGENDY WOKÓŁ SPALENIA WASZYNGTONU W 1814 ROKU
}

\begin{abstract}
Streszczenie. Miasto federalne, jak nazywano Waszyngton, miało dla Amerykanów znaczenie symboliczne. Było zarówno stolicą, jak i symbolem władzy federalnej. Zostało w $1790 \mathrm{r}$. wyznaczone na mapie, a po dziesięciu latach miały tam funkcjonować najważniejsze organy władzy. Dla Brytyjczyków stanowiło cel jedynie w ramach rewanżu za spalenie stolicy Kanady. Brytyjczycy weszli do Waszyngtonu nocą 24 sierpnia 1814 r. Rozpoczęli systematyczne niszczenie budynków państwowych. W ciągu 26 godzin podpalili Kapitol, dom prezydenta i inne kluczowe obiekty. Waszyngton płonął. Na szczęście prawie nie było w nim mieszkańców, którzy zdołali uciec. Tornado o niespotykanej sile, a następnie burza i ulewa dopełniły katastrofy - jednak ochroniły miasto przed całkowitym zniszczeniem przez Brytyjczyków, dlatego uważa się, że „burza ocaliła Waszyngton”.
\end{abstract}

Słowa kluczowe: Waszyngton, spalenie Waszyngtonu, wojna amerykańsko-brytyjska, bitwa pod Bladensburgiem, George Cockburn

\section{Miasto federalne jako symbol nowego państwa}

Artykuł jest syntezą wielu wątków dotyczących roli nowej stolicy państwa, jaką był Waszyngton. Duma i symbol niepodległego federalnego państwa, nazwana na cześć najwybitniejszego Ojca Założyciela, którym był George Washington, ledwo poczęła pełnić funkcję stolicy, a o mały włos nie podniosłaby się z popiołów. Duch amerykańskiej niepodległości i republikańsko-demokratycznych zasad opartych na narodowej dumie nie pozwolił wszakże, aby miasto to pozostało zniszczone i nigdy nieodbudowane. Wiele materiałów wykorzystanych do napisania niniejszego artykułu zostało zaczerpniętych z Internetu, głównie amerykańskich stron rządowych, które zawierają rzetelne opisy, a także 
materiały źródłowe. Jakkolwiek dużo faktów znanych jest dobrze w amerykańskiej historiografii, to jednak ujęcie całościowe, uwzględniające inne niż militarne aspekty, nie pojawia się w amerykańskiej historii. Fakty wybiórcze są dostępne zarówno w opracowaniach, jak i w Internecie, natomiast synteza połączona z głębszą analizą i interpretacją nie jest domeną amerykańskiej historiografii. W polskiej amerykanistyce fakt spalenia Waszyngtonu w czasie wojny amerykańsko-brytyjskiej jest sygnalizowany, acz nieopisywany w szerokim ujęciu. Zatem artykuł oferuje polskiemu czytelnikowi możliwie najbardziej wyczerpujące, a jednocześnie przystępnie podane informacje dotyczące spalenia Waszyngtonu w czasie wojny lat 1812-1814. Fakty są tutaj bezsporne, przy czym ich amerykańskie ujęcie odbiega nieraz od krytyki historycznej. Jako że amerykańska interpretacja wzmacnia poczucie dumy narodowej Amerykanów, pozwoliłam sobie na zaprezentowanie wydarzeń z 1814 r., w dużej mierze przedstawiając amerykański punkt widzenia. Dodałam informacje niezbędne do zrozumienia tego, czym było dla nich wówczas małe i jeszcze niedokonczone w budowie miasteczko i jak było ono postrzegane przez szukających odwetu Brytyjczyków. Żywioł wody i powietrza, który w efekcie ocalił stolicę, tak pięknie eksponowany przez Amerykanów, zastanawia i pozostawia znaki zapytania. Czy Opatrzność, która towarzyszyła Ojcom Pielgrzymom, zawsze pomagała Amerykanom? Czy odwoływanie się do niej nie jest swoistą, ale jakże piękną interpretacją historii? Odpowiedzi na te pytania pozostawiam Czytelnikowi. Zatem prześledźmy krótką historię Waszyngtonu oraz zobaczmy, dlaczego wojska brytyjskie z tak wielką determinacją dążyły do całkowitego zniszczenia miasta, które nie miało znaczenia strategicznego, było w trakcie realizowania planów architektonicznych, powstawało na tzw. gołej ziemi, nie miało tradycji. Tak bardzo zniszczone miasto zostało, co najważniejsze, przez Amerykanów nie tylko odbudowane, ale i rozbudowane. Nie utraciło też swego symbolicznego znaczenia dla mieszkańców Stanów Zjednoczonych.

Mieszkańcy byłych 13 kolonii, a od ogłoszenia w 1776 r. Deklaracji Niepodlegtości Stanów Zjednoczonych Ameryki, po zakończeniu wygranej wojny o niepodległość (1775-1783) rozpoczęli budowę nowego państwa. Pierwotna koncepcja ustrojowa, jaką była konfederacja przyznająca bardzo dużą swobodę stanów, nie sprawdziła się w praktyce. Państwu groził rozpad oznaczający zniweczenie dzieła dziewięcioletniej wojny z Wielką Brytanią. Trzeba było stworzyć nowy system. Był nim federalizm, podporządkowujący członkowskie stany Unii 
silnej władzy federalnej, który wprowadziła konstytucja 1787 r. Tak jak tworzenie nowych zasad ustrojowych, tak samo ważne było dla Stanów Zjednoczonych kreowanie nowej tradycji politycznej, szukanie symboli, które odcinałyby się od czasów kolonialnych.

Jednym z takich symboli było zbudowanie od podstaw miasta, które byłoby stolicą Stanów Zjednoczonych ${ }^{1}$. Określano je jako miasto federalne (federal city) bądź jako stałą rezydencję (permanent residence) władz federalnych, a więc Kongresu, prezydenta i Sądu Najwyższego. Decyzja o utworzeniu nowego miasta jako siedziby władz federalnych zapadła w rok po wejściu konstytucji w życie. Dnia 16 lipca 1790 r. w wyniku tzw. kompromisu 1790 r. została podpisana Ustawa Rezydencyjna (Residence Act) ${ }^{2}$, która wydzielała ziemię nad Potomakiem oddaną przez stany Maryland i Wirginia na utworzenie niezależnego od żadnego stanu terytorium, podlegającego wyłącznie jurysdykcji Kongresu ${ }^{3}$. Ten tzw. obszar federalny miał zajmować nie więcej niż 100 mil kwadratowych, po 10 mil z każdej strony (ten miles square), czyli ok. 260 kilometrów kwadratowych ${ }^{4}$. Wyznaczenie lokalizacji miasta przypadło w udziale George'owi Washingtonowi, tak jak i wybranie trzech komisarzy odpowiedzialnych za jego budowę. Ustawa zapowiadała, że przez pierwszych 10 lat od daty podpisania ustawy, na czas wznoszenia miasta federalnego, stolicą państwa będzie miasto Filadelfia. Miała nią być „aż do pierwszej niedzieli grudnia 1800 roku” bardzo słuszny wybór, gdyż w pięknym i bogatym mieście, jakim była Filadelfia, najdłużej gościła najwyższa władza rewolucji amerykańskiej, tj. Kongres Kontynentalny ${ }^{6}$. Te 10 lat miało być dostatecznie długim terminem na zbudowanie od podstaw budynków federalnych, jak i miasta. Już bowiem od pierwszego poniedziałku grudnia 1800 r. miała funkcjonować nowa stolica.

${ }^{1}$ Vide: J.A. DAsZyńsKa, Narodziny tradycji. Symbole amerykańskiej demokracji, Łódź 2010, s. 77-81.

2 The Residence Act of 1790 to ustawa pt. An Act for Establishing the Temporary and Pernament Seat of the Government of the United States - tekst vide: www.ushistory.org/presidentshouse/history/ act1790.htm (dostęp: 18 XI 2020).

3 Więcej na temat Kompromisu 1790 r. - vide: J.A. DASZYŃSKA, op. cit., s. 78.

${ }^{4} \mathrm{Na}$ temat wyboru lokalizacji - vide: K.R. Bowling, The Creation of Washington, D.C.: The Idea and Location of the American Capital, Fairfax, Va. 1991.

5 Cit.per: J.A. Daszyńska, Kryzysy ikompromisy w Stanach Zjednoczonych Ameryki czasów Ojców Zatożycieli, Łódź 2018, s. 71.

${ }^{6}$ Ze względu na toczące się działania wojenne stolicę z Filadelfii przenoszono również do innych, bezpieczniejszych miast, którymi były: Princeton, New Jersey, Annapolis, Maryland, Trenton i New York. 
W 1790 r. wyznaczony obszar federalny był tylko miejscem na mapie, porośniętym łąkami i drzewami. Było tam kilka farm, a także miasteczka nad Potomakiem: Georgetown (leżące przed ogłoszeniem ustawy w Marylandzie, czyli od północy) i Alexandria (w Wirginii, zatem od południa). Miejscowości te zostały założone dość niedawno, gdyż Georgetown w 1751 r., a Aleksandria w 1749 r. Dopiero w 1801 r. zostały one oficjalnie włączone do Dystryktu Kolumbia?.

Przez dwa lata (1791-1792) granice terytorium dystryktu zaznaczano kamieniami (boundary stones), kładąc je co każdą milę ${ }^{8}$. Kongres wystąpił z wnioskiem o nadanie nazwy powstającemu miastu. W dniu 9 września 1791 r. uznano, że miasto federalne (Federal City), jak dotychczas powszechnie mówiono o nowej stolicy, na cześć głównodowodzącego Armią Kontynentalną, Ojca Założyciela (Founding Father) i pierwszego prezydenta zostanie nazwane jego imieniem. Nazwa ta weszła natychmiast w życie. Oficjalnie brzmiała: Washington City (Miasto Waszyngton ${ }^{9}$ ). Dopiero po dziesięciu latach, na mocy ustawy District of Columbia Organic Act of 1801, obszar federalny wyznaczony pod budowę stolicy nazwano Dystryktem Kolumbia (District Columbia, w skrócie pisane jako D.C.), przypominając tym samym Krzysztofa Kolumba jako odkrywcę Ameryki. Było to również nawiązanie do czasów wojny o niepodległość, kiedy „Columbia" oznaczało patriotyczne odniesienie do Stanów Zjednoczonych.

Również w 1791 r. prezydent G. Washington wyznaczył trzech komisarzy, których zadaniem był nadzór nad wykonaniem projektu wzniesienia nowej siedziby władz. Do ich kompetencji należało również wypłacanie odszkodowań za te posiadłości, które musiały zostać opuszczone, choć nie zawsze się to udawało ${ }^{10}$. Pominę ogromnie ciekawe sprawy dotyczące wizji architektonicznych odnoszących się do nowej stolicy, które miały albo przyćmić nawet europejski Wersal, albo nawiązywać do urody Paryża, Londynu, Madrytu czy Amsterdamu lub też urzekać skromnością idei demokratycznych. W efekcie ta druga koncepcja zwyciężyła, a miasto budowane w błocie powoli zaczynało nabierać kształtu.

${ }^{7}$ Regulowat to District of Columbia Organic Act of 1800. Mieszkańcy Georgetown i Aleksandrii przestali być uznawani za rezydentów stanu Wirginia i Maryland, co spowodowało skutek uboczny - brak reprezentacji w Kongresie. Vide: Statement on the subject of The District of Columbia Fair and Equal Voting Rights Act, American Bar Association, September 14, 2006 (Retrieved August 10, 2011).

${ }^{8}$ F.M. Bordewich, Washington: The Making of the American Capital, New York 2008, s. 76-80.

9 W pracy używam polskiej pisowni dla miasta, pisząc Waszyngton, i angielskiej dla nazwiska Washington.

${ }^{10}$ Vide: np. problemy z ,upartymi posiadaczami ziemskimi” - J.T. FLEXNER, George Washington and the New Nation (1783-1793), Boston-Toronto 1970, s. 326. 
Kamień węgielny pod budowę Kapitolu przeznaczonego na siedzibę Kongresu położył sam G. Washington 18 września 1793 r. Co ciekawe, dom dla prezydenta, znany później w historii jako Biały Dom, miał kamień węgielny położony o rok wcześniej. Teren podzielono na szereg parceli i wystawiono ofertę ich sprzedaży, aby przyciągnąć nowych mieszkańców. Dwóch finansistów (Robert Morris i James Greenleaf) zakupiło cały proponowany teren składający się z 6 tys. działek po 80 dolarów.

W nowo powstającym mieście brak było jednak wszystkiego, do czego przyzwyczajeni byli chociażby członkowie Kongresu. Wiedziano, że jest to symbol tworzącego się państwa, ale zgodnie uważano, że jest to po prostu dziura. Takie zdanie mieli Abigail Adams, jak i np. prokurator generalny Richard Rush, który opisywał to miasto jako „małą mieścinę z nędznymi domami i rozległymi bagnami" ${ }^{\prime \prime}$. Nawet oba federalne budynki - w jednym miał zasiadać Kongres, a drugi przeznaczono na siedzibę prezydenta - nie były ukończone. Ukończono tylko jedno skrzydło Kapitolu. Jednakże latem 1800 r. do Waszyngtonu zaczęli przyjeżdżać federalni urzędnicy. Było ich ponad stu. Pojawił się problem z ich zakwaterowaniem, gdyż w nowym mieście nie wybudowano jeszcze domów. Dlatego też w bardzo szybkim tempie postawiono 372 drewniane domy przeznaczone dla senatorów i kongresmenów. Mimo wielu braków domy te stanowiły ich własność, w przeciwieństwie do wynajmowanych w Nowym Jorku czy Filadelfii.

Pierwszego listopada $1800 \mathrm{r}$. do Waszyngtonu przyjechał prezydent J. Adams, któremu towarzyszyła małżonka Abigail. W swoich pamiętnikach opisała obraz budującego się miasta, którym była jednak bardzo rozczarowana. W dniu 17 listopada zwołano pierwsze posiedzenie członków Kongresu, które ze względu na słabe warunki lokalowe odbyło się w skrzydle Senatu ${ }^{12}$.

Dopiero w przyszłym roku przybyli sędziowie Sądu Najwyższego. Nie mieli jeszcze wybudowanego budynku sądu. Zmuszeni byli zamieszkać i prowadzić posiedzenia w małym biurze senackiego urzędnika. Trzeci filar władzy przez długie lata traktowany był inaczej niż dwa pozostałe. Dom prezydenta czy Kapitol przeznaczony dla władzy ustawodawczej zostały w miarę ukończone i spełniały swe funkcje państwowe. Tymczasem sędziowie Sądu Najwyższego swój odrębny, okazały gmach otrzymali dopiero w 1935 r. Prace budowlane trwały

\footnotetext{
${ }^{11}$ Cit.per: https://www.whitehousehistory.org/the-burning-of-washington (dostęp: 22 XI 2020).

12 Posiedzenie rozpoczęło się 17 XI 1800 r. Vide: https://history.house.gov/Institution/Firsts-Milestones/First-Meetings/ (dostęp: 18 XI 2020).
} 
przez kolejne lata. Dopiero w 1807 r. kongresmeni izby niższej mogli przenieść się do swojego skrzydła przeznaczonego dla Izby Reprezentantów, co nie oznaczało, że prace budowlane były tam zakończone - ukończono je w 1811 r. Obie izby Kongresu były połączone ze sobą drewnianym przejściem.

Miasto jednak się rozwijało, o czym świadczy liczba ludności. W 1790 r. była bliska zera. Dziesięć lat później miasto wraz z Dystryktem Kolumbia było zamieszkiwane przez 14 tys. ludzi, z tego białych 10 tys. i 4 tys. czarnych (783 wolnych Murzynów i ok. 3,2 tys. niewolników), a w 1810 r. było już 24 tys. mieszkańców, w tym 16 tys. białych i 7,9 tys. czarnych (wolnych 2,5 tys. oraz 5,3 tys. niewolników) ${ }^{13}$. Waszyngton stawał się symbolem władzy federalnego państwa, tworzonym od podstaw na gołej ziemi. Trudności z budową, a więc i z funkcjonowaniem w niczym nie umniejszały jego znaczenia. Jak tylko można wzmacniano znaczenie nowej stolicy, co było bardzo spektakularne, gdy zaczęły się tam odbywać inauguracje prezydenckie ${ }^{14}$. Prezydentem, który po raz pierwszy składał przysięgę na Kapitolu, był Thomas Jefferson w dniu 4 marca 1801 r. Bez wątpienia Waszyngton wzmacniał swą pozycję jako stolica państwa, a więc siedziba jego najwyższych władz. Był rodzącym się symbolem amerykańskiej demokracji. Wiedzieli o tym Amerykanie, jak i Brytyjczycy. Ci ostatni jednak niechętnie przybywali tam w roli dyplomatów, uważając Waszyngton za całkowitą dziurę, w której nie ma żadnych rozrywek, a jedynie bagna ${ }^{15}$.

\section{Wojna 1812-1814}

W roku 1812 doszło do otwartej wojny między Stanami Zjednoczonymi a Wielką Brytanią. Powodów było wiele. Ogłosił je w swym przemówieniu (War Message) prezydent James Madison ${ }^{16}$. Nie była ona zaskoczeniem, przeciwnie

13 Dane na podstawie: The District of Columbia. The Seat of Government, New York 1969, s. 36; https://matthewbgilmore.wordpress.com/district-of-columbia-population-history/ (dostęp: 21 XI 2020).

${ }^{14}$ Pierwszy prezydent, którym był George Washington, został zaprzysiężony w Nowym Jorku, drugi, czyli John Adams - w Filadelfii, a dopiero Thomas Jefferson jako trzeci prezydent Stanów Zjednoczonych zapoczątkował inauguracje w Waszyngtonie.

15 Dobitnie określił to Augustus John Foster, ostatni brytyjski dyplomata w Stanach Zjednoczonych przed wybuchem wojny: ,an absolute sepulcher, this hole” - cit.per: https://www.whitehousehistory.org/the-burning-of-washington (dostęp: 23 XI 2020).

${ }^{16}$ James Madison, War Message, 1 VI 1812 - vide: https://loveman.sdsu.edu/docs/1812SpecialMessagetoCongresswarmessage.pdf (dostęp: 19 XI 2020). 
- dla jej orędowników zwanych War Hawks (wojenne jastrzębie) była doskonałą okazją do dalekosiężnych planów zdobycia Kanady. W Ameryce do wojny parły typowo rolnicze stany, w tym zarówno farmerskie, jak i plantatorskie. Madison umiejętnie przedstawił niemal katastroficzny w skutkach obraz zniszczenia państwa przez Anglików, pogwałcenie honoru i flagi, załamanie handlu, konfiskaty towarów na statkach, impressment. Faktycznie impressment był odczuwalny, ale nie stanowił głównej podstawy do wypowiedzenia wojny. Prawdą jest, że stosunki amerykańsko-angielskie nie należały do najlepszych, ale wojny można było uniknąć. Doskonale rozumiał to poprzedni prezydent Thomas Jefferson. Jego następca James Madison dał się ponieść nastrojom wojennym. Jego War Message jest doskonałym przykładem politycznej propagandy.

Jego zdaniem najbardziej narażone na brytyjskie ataki powinny być stany północno-wschodnie, określane jako handlowo-żeglugowe. Tymczasem właśnie one były przeciwko wojnie! Ich gospodarka była oparta na handlu, żegludze i przemyśle, a więc według słów, jakie padły w orędziu prezydenta J. Madisona, to one najbardziej cierpiały i one powinny dążyć do wojny. Rzeczywistość okazała się całkiem inna. Do wojny parły stany zachodnie i południowe, które widziały w wojnie szansę na zdobycie Kanady. To ich przedstawiciele, tacy jak Speaker Izby Reprezentantów Henry Clay z Kentucky czy John C. Calhoun z Południowej Karoliny, byli jastrzębiami. Jednak o planach podboju Kanady prezydent J. Madison nie wspomniał w swym orędziu. Nastroje wojenne mimo wszystko przeważyły. W Izbie Reprezentantów za wojną głosowało 79 kongresmanów, przeciwko - 49, a w Senacie ta przewaga była już znaczna $(19 \text { do } 3)^{17}$. Umiejętnie bowiem nagłośniono incydent związany z brytyjskim okrętem wojennym „Leopard”, który 22 czerwca 1807 r. zaatakował i przejął amerykańską fregatę "Chesapeake”, jak i kolejne tego rodzaju zdarzenia - np. w 1811 r. amerykański statek U.S.S. „President” został ostrzelany przez brytyjską jednostkę "Little Belt”. Na wzrost nastrojów wojennych wpływ miało też indiańskie powstanie Tecumseha, a zwłaszcza wieści, jakie obiegły Amerykę po jego stłumieniu. Okazało się bowiem, że Indianie byli wyposażeni w najnowsze brytyjskie karabiny. Nastroje wojenne potęgowały się w społeczeństwie. Przypieczętował je prezydent J. Madison, podpisując 18 czerwca 1812 r. deklarację wojny.

${ }_{17}$ Quia notitia: M.A. Jones, Historia USA, przekł. P. KUROWSKI, P. OSTASZEWSKI, Gdańsk 2002, s. 120 . 
Wypowiedzenie wojny kładło kres zasadzie neutralności ustanowionej przez pierwszego amerykańskiego prezydenta (1793), a także wysiłkom prezydenta T. Jeffersona, który wprowadził embargo, aby uniknąć konfliktu zbrojnego z Wielką Brytanią (1807 i 1809). Społeczeństwo uwierzyło, że Anglicy rujnują amerykańską żeglugę handlową, a zatem cały amerykański handel i gospodarkę. Wojna była spóźniona o kilka lat, bo faktycznie incydent z Chesapeake mógł wówczas do niej doprowadzić, ale sprzeciwił się jej prezydent T. Jefferson. Jego następca, prezydent J. Madison, dał się unieść prowojennym nastrojom ${ }^{18}$. Wojna stała się faktem. Dzień 18 czerwca 1812 r. przyjmuje się za jej rozpoczęcie. Toczyła się głównie w południowej i wschodniej części Stanów Zjednoczonych oraz na wodach oceanów Spokojnego, Atlantyckiego i Indyjskiego. Stany Zjednoczone przeciwstawiły się największej potędze morskiej, jaką była wówczas Wielka Brytania.

Nasuwa się pytanie, dlaczego to właśnie stany żeglugowo-handlowe, a więc północno-wschodnie, nie poparły wojny, skoro - według słów J. Madisona - tak bardzo cierpiały ich interesy. Dlaczego wspierały ją i do niej podżegały stany południowo-zachodnie, które nie odczuwały skutków impressmentu? Odpowiedź jest taka, że chodziło o znalezienie pretekstu do zawładnięcia Kanadą, odegranie się na Brytyjczykach za czasy kolonialne i do zaspokojenia dążeń ekspansjonistycznych.

Wojna trwała 32 miesiące, a więc ponad dwa i pół roku ${ }^{19}$. Oprócz działań na oceanach walki toczyły się też na terytorium Stanów Zjednoczonych, głównie w rejonie Wielkich Jezior i na wschodnim wybrzeżu, zwłaszcza w stanach południowych. Jednak nie ominęły też nowej stolicy.

\section{Atak na Waszyngton}

Rok 1814 przyniósł ogromną zmianę na frontach walk brytyjsko-amerykańskich. Brytyjczycy mogli skoncentrować swe działania wyłącznie na wojnie z A merykanami, gdyż po klęsce Napoleona i jego abdykacji 6 kwietnia stworzyła

$18 \mathrm{~W}$ orędziu prezydent położył nacisk na dumę narodową Amerykanów pogwałcaną przez Anglików, na bezczeszczenie praw, naruszanie portów, neutralności handlowej, impressment, szydzenie z flagi i tym podobne kwestie. Mimo rozłamu w społeczeństwie co do odejścia od polityki neutralności wojnę jednak przegłosowano w Kongresie. Vide: J.A. DASZYŃSKA, Kryzysy i kompromisy..., s. 192.

19 Wojna została zakończona podpisaniem pokoju w Gandawie, w Wigilię 1814 r., choć w Ameryce bitwy trwały nadal, w tym najsłynniejsza pod Nowym Orleanem, która była dla Amerykanów zwycięska. Dała podwaliny do odbudowy dumy narodowej. 
się dla nich nowa sytuacja. Mogli więc w Ameryce przejść z działań obronnych na ofensywne. Wzmocnili swe siły, na początku czerwca ściągając do Kanady wojska zajęte dotąd walkami z Francją. W sumie przypłynęło 13 tys. zaprawionych w boju żołnierzy, zwiększając siły stacjonujące w Kanadzie do 30 tys. Brytyjczycy planowali jeszcze do końca roku pokonać amerykańską flotę na jeziorach Erie i Champlain oraz zająć forty Niagara i Detroit. Jak się okazało, plany te się nie powiodły, głównie na skutek błędów w kampanii prowadzonej przez gen. George’a Prevosta, który jako głównodowodzący siłami brytyjskimi w Ameryce Północnej podjął się stoczenia bitwy jednocześnie na lądzie i mo$\mathrm{rzu}^{20}$. Po klęsce wojsk brytyjskich został on pozbawiony urzędu gubernatora Kanady. Miał oczyścić swój honor przed sądem wojennym w Londynie, ale zmarł nagle kilka dni przed rozprawą.

Amerykanie również popełniali błędy taktyczne, nie mieli „jasnego planu działań wojskowych" ${ }^{21}$. W dodatku pogorszyła się ich sytuacja ekonomiczna na skutek brytyjskiej blokady morskiej i braku poparcia stanów północnych dla wojny.

W styczniu 1814 r. Kongres próbował zwiększyć liczebność Armii Kontynentalnej, jednak powołano tylko 6 tys. żołnierzy. Nie dość, że było ich za mało, to jeszcze nie mieli oni dobrego wyszkolenia. Wojsko nie otrzymywało też zaopatrzenia, były problemy z aprowizacją. Ponadto Brytyjczycy atakowali w różnych miejscach, zarówno na Wielkich Jeziorach, jak i na lądzie.

Brytyjski plan ataku zakładał również zajęcie Waszyngtonu. Miasto to nie miało znaczenia strategicznego, ale Anglicy doskonale zdawali sobie sprawę, że jest symbolem, a jego opanowanie miałoby ogromne znaczenie propagandowe. Robert Kłosowicz pisze, że „dowództwo brytyjskie liczyło, że zdobycie stolicy nieprzyjaciela nadszarpnie jego morale, spowoduje zamieszanie w zarządzaniu państwem i w rezultacie zmusi Amerykanów do ustępstw podczas rokowań pokojowych"22.

Brytyjskie oddziały piechoty morskiej dokonywały ataków na osady położone wzdłuż wybrzeża, grabiąc je i niszcząc. Miały bowiem „sprawić Amerykanom

${ }^{20}$ Sir George Prevost (1767-1816) - gubernator generalny Brytyjskiej Ameryki Północnej, głównodowodzący w Ameryce Północnej, generał (Lieutenant General), vide: https://www.battlefields.org/learn/biographies/george-pr\%C3\%A9vost (dostęp: 21 XI 2020).

${ }^{21}$ R. KŁosowiCZ, Wojna amerykańsko-brytyjska 1812-1814, Kraków 2003, s. 165.

${ }^{22}$ Ibidem, s. 177. 
tęgie lanie”, jak określił to admirał Thomas Alexander Cochrane ${ }^{23}$. Oficjalnym pretekstem było spalenie przez amerykańskich żołnierzy w 1813 r. osady Newark w Górnej Kanadzie, a przede wszystkim Yorku (dziś Toronto) będącego stolicą Kanady. Atak na Waszyngton miał być dopełnieniem tego planu.

$\mathrm{Na}$ początku kwietnia 1814 r. brytyjska eskadra popłynęła do ujścia rzeki Connecticut. W dniu 7 kwietnia brytyjski desant w sile 200 ludzi przewiezionych na łodziach desantowych wdarł się 6 mil w górę rzeki do miejscowości Pettipaug. Po krótkiej walce z zaskoczonymi oddziałami amerykańskiej milicji Brytyjczycy zniszczyli 27 cumujących tam statków wraz ze 134 działami, a także spalili zapasy wojskowe. W czerwcu zaś doszło do połączenia brytyjskich sił morskich, które liczyły 4 okręty liniowe, 20 fregat i slupów oraz 20 transportowców. Kontradmirał George Cockburn, dowodzący eskadrą brytyjską kontrolującą wybrzeża Marylandu i Wirginii, dał się poznać A merykanom jako brutalny dowódca i podżegacz wojenny, organizując napady na miejscowości położone wzdłuż Zatoki Chesapeake. To on kazał splądrować i zniszczyć Havre de Grace, Hampton i Frenchtown ${ }^{24}$. To on był inicjatorem planu ataku na Waszyngton, to on osobiście podkładał ogień. Polecił przeprowadzenie operacji desantowej pod St. Benedict. Miasteczko to leżało nad Zatoką Chesapeake u ujścia rzeki Patuxent. Co ważniejsze, było ono połączone drogą z Waszyngtonem, a odległość nie była zbyt duża, gdyż wynosiła 45 mil. Ponadto G. Cockburn do udziału w walkach na lądzie włączył generała Roberta Rossa, którego marzeniem było zdobycie amerykańskiej stolicy.

Można zadać pytanie, co robili wówczas Amerykanie, a zwłaszcza osoby odpowiedzialne za obronę. Otóż nic. Po pierwsze dlatego, że sekretarz wojny John Armstrong nie wierzył, aby Brytyjczycy mieli w planach zaatakowanie Waszyngtonu, poniekąd słusznie sądząc, że nie ma on żadnego strategicznego znaczenia. Po drugie, obszar wzdłuż Zatoki Chesapeake nie został ani umocniony, ani obsadzony przez amerykańskich żołnierzy. Były tam jedynie oddziały stanowej milicji, ale zupełnie nieprzygotowane, w dodatku bez wystarczającego uzbrojenia. Dopiero gdy w czerwcu 1814 r. zauważono zwiększoną aktywność

\footnotetext{
${ }^{23}$ Cit. per: ibidem, s. 177.
}

Thomas Alexander Cochrane (1758-1832) - brytyjski komandor (vice admiral): https://www. battlefields.org/learn/biographies/alexander-cochrane (dostęp: 21 XI 2020).

${ }^{24}$ George Cockburn (1772-1853) - brytyjski admiral floty: https://www.nps.gov/people/george-cockburn.htm (dostęp: 21 XI 2020). 
brytyjskiej floty w Zatoce Chesapeake - Amerykanie zaczęli działać. Wzmocniono siłę floty przez dołączenie do sił marynarki około tysiąca marynarzy z floty handlowej. Stany sąsiadujące z D.C. zobowiązały się dostarczyć oddziały milicji. W dniu 2 lipca utworzono Dziesiąty Okręg Wojskowy - objęto nim także miasto Waszyngton. Dowództwo okręgu powierzono gen. Williamowi H. Winderowi. Przybył on wkrótce do miejscowości Bladensburg. Czynił nawet przygotowania do obrony, ale wobec braku żołnierzy był bezsilny. Z powołanych do oddziałów milicji 3 tys. ludzi stawiło się zaledwie 250 osób. Prośby i rozkazy do władz federalnych o uzupełnienie stanu pozostawały bez odpowiedzi. Na siły wojskowe też nie mógł liczyć, bo „najbliższa brygada regularnego wojska liczyła 2 tys. i nie osiągnęła jeszcze stanu gotowości bojowej”25.

W dniu 20 sierpnia Brytyjczycy pokazali, że ich celem jest Waszyngton. Poprzedniego dnia ich okręty zacumowały w pobliżu St. Benedict (Maryland). Rankiem załoga spokojnie wyszła na ląd, gdyż amerykańskie okręty, którymi dowodził kpt. Joshua Barney, na sam widok angielskiej floty odpłynęły. W dodatku mieszkańcy St. Benedict również uciekli, dosłownie niemal tak, jak stali. Niezatrzymywane przez nikogo wojska brytyjskie kontynuowały marsz w głąb lądu. Pokonując 20 mil, pod wieczór dotarły do Nottingham, co było bezspornym dowodem, że idą zdobyć stolicę amerykańskiego państwa. Tragizm sytuacji powiększył się, gdy kapitan Barney, napotkawszy angielską blokadę, która uniemożliwiła mu wypłynięcie z Zatoki Chesapeake, rozkazał spalić własne okręty.

Następnego dnia, tj. 21 sierpnia, Brytyjczycy dotarli do Górnego Marlborough. Tam wojska miały odpoczywać, a w tym czasie Ross z Cockburnem naradzali się co do dalszego postępowania. Brytyjczycy mieli dwa warianty ataku na Waszyngton. Pierwszy zakładał uderzenie wprost na stolicę, drugi - przez zdobycie Bladensburga. Pierwszy wariant niósł w sobie niebezpieczeństwo, że Amerykanie zdołają umocnić swoje pozycje obronne, a więc istniało ryzyko, że Anglicy wpadną w pułapkę. Drugi wariant oznaczał pójście w kierunku północno-zachodnim, zdobycie Bladensburga, a potem przejście przez rzekę Anacostia i dopiero wtedy ruszenie bezpośrednio na Waszyngton. Za tym wariantem przemawiało to, że od strony północnej Waszyngton nie był umocniony, a więc otwarty na atak. To przeważyło.

Zatem po południu w dniu 23 sierpnia wojska brytyjskie skierowały się na Bladensburg. Maszerowały, nawet gdy zapadła noc. Moim zdaniem chodziło

\footnotetext{
${ }^{25}$ R. KŁOsowicZ, op. cit., s. 180.
} 
nie tylko o to, aby zająć pozycje i rankiem zaatakować niczego niepodejrzewających Amerykanów, ale i o wykorzystanie chłodu nocy. Od kilku tygodni nie spadła kropla deszczu, a upały były dotąd nienotowane. Plan brytyjski zakładał także wariant odwrotu, gdyby atak się nie powiódł. W Górnym Marlborough pozostał oddział piechoty morskiej, który miał przygotować pozycje dla wycofujących się Brytyjczyków, gdyby nie udało się im zdobyć Bladensburga.

W tym samym czasie amerykański dowódca gen. William $\mathrm{H}$. Winder nadal oczekiwał na posiłki i instrukcje, ale się ich nie doczekał. Dokładnie 23 sierpnia otrzymał wiadomość, że Brytyjczycy wyruszyli w jego kierunku. Pośpiesznie nakazał rozlokowanie swych sił, ale ze względu na brak wyszkolonych żołnierzy opierał się przede wszystkim na niewyszkolonych oddziałach milicji. Na szczęście dołączył do nich Joshua Barney wraz z marynarzami ze spalonej floty.

Bladensburg stał się kluczową pozycją na drodze do zajęcia (Brytyjczycy) lub obrony (Amerykanie) Waszyngtonu. Nie wdając się w szczegóły bitwy, trzeba stwierdzić, że siły obu stron były niemal wyrównane, z przewagą po stronie amerykańskiej (6,5 tys. Amerykanów, 4,5 tys. Brytyjczyków) ${ }^{26}$. Amerykanie mieli też dogodniejsze pozycje. Ich wojska i artyleria czekały na wzgórzach z widokiem na most, przez który mieli przejść Anglicy. Ci jednak, mając rozpoznanie z poprzedniego dnia, wiedzieli o tym, więc w południe ominęli most i przekroczyli rzekę od strony północnej. Ostrzelali pozycje amerykańskich żołnierzy, którzy, po pierwsze, byli rozlokowani w zbytnim rozproszeniu, a po drugie, nie mając odpowiedniego wyszkolenia, spanikowali, a gen. Wilder nie panował nad sytuacją. Amerykańska milicja poszła w rozsypkę pod wrażeniem brytyjskiego ostrzału. Nastąpiła rzecz niebywała. Amerykanie uciekali z pola walki. Dlatego też prawie nikogo nie wzięto do niewoli. Według słów jednego z brytyjskich oficerów „Amerykanie uciekali zbyt szybko, aby ich złapać" ${ }^{27}$. Słabo przygotowani i marnie uzbrojeni, woleli czmychnąć do domów, by chronić swoje rodziny, niż stawiać czoła potężnemu przeciwnikowi. Należy podkreślić, że wiele z tych brytyjskich relacji miało charakter propagandowy, toteż starano się wyszydzić siły przeciwnika. Uwzględniając wszakże czas trwania bitwy, trzeba powiedzieć, że tak łatwo Amerykanie się

${ }^{26}$ Cf: : ibidem, s. 181. R. Kłosowicz podał, że Amerykanie mieli ok. 6. tys. żołnierzy, a Anglicy 4,5 tys. Różnice w owych szacunkach są jednak znaczne - vide: np. 1,5 tys. Brytyjczyków, 5 tys. Amerykanów, https://www.nps.gov/articles/bladensburg-races.htm (dostęp: 22 XI 2020). Bardziej wiarygodne dane są dostępne pod adresem: https://www.battlefields.org/learn/war-1812/battles/bladensburg (dostęp: 22 XI 2020), gdzie podano, że siły amerykańskie liczyły 6,5 tys. ludzi, a brytyjskie 4,5 tys.

${ }^{27}$ Cit. per: https://www.nps.gov/articles/bladensburg-races.htm (dostęp: 22 XI 2020). 
nie poddali, gdyż walki prowadzono przez ponad trzy godziny ${ }^{28}$. Ponadto straty po obu stronach były podobne. Rannych żołnierzy brytyjskich było 250, a amerykańskich $200^{29}$. Biorąc pod uwagę doskonałe wyposażenie i wyćwiczenie Brytyjczyków, a mizerne Amerykanów i ich nieobycie w walkach, trzeba przyznać, że wojsko amerykańskie broniło się dzielnie. Niemniej przegrana Amerykanów otworzyła Brytyjczykom dowodzonym przez generała Roberta Rossa drogę do Waszyngtonu. Ich plan zniszczenia symbolu amerykańskiego państwa był na wyciągnięcie ręki. Był to doskonały rewanż za spalenie przez Amerykanów Yorku, stolicy Kanady, w dniu 27 kwietnia 1813 r. Waszyngton leżał nieopodal, gdyż odległość z Bladensburga wynosiła 8,6 mili, czyli 13,8 kilometra.

\section{Podpalenie Waszyngtonu - 26 godzin niszczenia miasta}

Wieści o klęsce rozeszły się błyskawicznie. Miał w tym swój udział prezydent J. Madison, który obserwował bitwę pod Bladensburgiem. Widząc, że zwycięstwo jest po stronie brytyjskiej, natychmiast wrócił do Waszyngtonu i nakazał pakowanie co ważniejszych dokumentów państwowych i wywiezienie ich w bezpieczne miejsce ${ }^{30}$. Zostało to zresztą wcześniej omówione z sekretarzem stanu. Prezydent prawdopodobnie zabrał najważniejsze dokumenty państwowe i pośpiesznie opuścił miasto. Dołączyła do niego żona. Według legendy uwiecznionej w malarstwie Dolley Madison zabrała zdjęty ze ściany obraz prezydenta G. Washingtona. Jednak to nie Dolley, a młody 15-letni niewolnik Paul Jennings, pracujący w domu prezydenta, zajął się ratowaniem najcenniejszych przedmiotów. W tym również portretu pierwszego prezydenta. Obraz był duży i dość wysoko zawieszony, więc Dolley nie była w stanie - zwłaszcza w pośpiechu - wyjąć z ram obrazu, w dodatku używając do tego drabiny. Miała to zrobić służba, wśród której był niewolnik nazwiskiem Jennings. Wspominał później, że to właśnie służba zajmowała się ratowaniem dobytku i drogocennych przedmiotów. To również służba, pozorując, że para prezydencka jest w domu, nakryła do stołu i wniosła dania. W jej szeregach byli m.in. John Susé, znany jako Jean Pierre Sioussat, francuski odźwierny,

${ }^{28}$ Vide: https://www.nps.gov/stsp/learn/historyculture/battle-of-bladensburg.htm (dostęp: 23 XI 2020).

${ }^{29}$ https://www.battlefields.org/learn/war-1812/battles/bladensburg (dostęp: 23 XI 2020).

${ }^{30}$ Vide: https://www.nps.gov/stsp/learn/historyculture/battle-of-bladensburg.htm (dostęp: 23 XI 2020). 
a także Mc Graw (lub Magraw), który był ogrodnikiem prezydenta, a w tym trudnym czasie wywiózł z rezydencji prezydenckiej kosztowności.

Dwóm urzędnikom Kongresu udało się uratować Deklarację Niepodlegtości, Konstytucję, korespondencję G. Washingtona, w tym jego Adres pożegnalny. Uczynili to, gdyż otrzymali instrukcje od sekretarza stanu Jamesa Monroe, który konno udawał się na zwiady ${ }^{31}$. Dzięki jego obserwacjom i poleceniom udało się ocalić nie tylko te dokumenty, ale i wiele innych wartościowych rzeczy, zanim do miasta wkroczyli Anglicy. Na szczęście posłuchano jego, a nie lekceważących niebezpieczeństwo słów sekretarza wojny. Para prezydencka zaś udała się do miejscowości Brookeville, oddalonej na północ od Waszyngtonu o $12 \mathrm{mil}$ (czyli ok. $20 \mathrm{~km}$ ), położonej w hrabstwie Montgomery w stanie Maryland. Madisonowie spędzili tam jedną noc, stąd to kwakierskie miasteczko nosi nazwę „jednodniowej stolicy Stanów Zjednoczonych”32. Gościny użyczył im kwakier Caleb Bentley, który przenocował parę prezydencką w swoim domu (dom ten stoi do dziś i znany jest jako Madison House/dom Madisona).

Ludzie zaczęli uciekać z Waszyngtonu, panika i groza były wszechobecne. Pospiesznie ładowany na wozy dobytek wysypywał się na ulice, wszędzie biegały wystraszone zwierzęta, które uciekły podczas tej bezładnej ewakuacji, a właściwie samowolnie podejmowanej decyzji o ucieczce. Najgorzej wyglądała sytuacja na moście przez rzekę Potomak, gdyż jednocześnie byli na nim wszyscy, zarówno przerażeni ludzie, ich dobytek na wozach i powozach, zwierzęta, jak i żołnierze. Drewniane mosty ledwo to wytrzymały. Sytuację utrudniała zapadająca noc. Mosty nie zostały także zniszczone w celu zatrzymania pochodu Brytyjczyków, co sugerował prezydentowi sekretarz stanu J. Monroe ${ }^{33}$.

Brytyjczycy dotarli pod Waszyngton o zachodzie słońca. Zostali „powitani” strzałami amerykańskich snajperów. Oddano je z domu na skrzyżowaniu Maryland Avenue, Constitution Avenue i Second Street. Pociski powaliły konia dowodzącego wojskiem gen. Roberta Rossa, zabiły jednego żołnierza, a drugiego

31 Byli to John McDonald i Lewis Machen, młodzi urzędnicy, którzy nie zostali powołani do milicji przez bałagan wynikający ze zmiany miejsca zamieszkania. Na własną rękę organizowali transport, co w obliczu paniki graniczyło niemal z cudem. Pomagał im Stephen Plesonton. Vide: https://www. whitehousehistory.org/the-burning-of-washington (dostep: 23.11.2020).

32 W oryginale: „United States Capital for a Day”.

33 James Monroe pisat: „The enemy are in full march to Washington. Have the materials to destroy the bridges" - https://www.nps.gov/stsp/learn/historyculture/battle-of-bladensburg.htm (dostęp: 23 XI 2020). 
zraniły. W odwecie dom, z którego padły strzały, został natychmiast podpalony $^{34}$. Brytyjczycy wciągnęli też na maszt Kapitolu flagę Union Jack, a do miasta weszli wieczorem. Zastali je niemal opustoszałe ${ }^{35}$. Większość mieszkańców uciekła. Nie było ich tak dużo, gdyż w samym mieście według spisu z $1810 \mathrm{r}$. mieszkało 8 tys. osób, w tym 1,3 tys. niewolników. Rozzuchwalone wojska brytyjskie, podjudzane przez Cockburna i Rossa, zaczęły podpalać budynki. Na pierwszy ogień poszły obiekty federalne, gdyż brytyjscy dowódcy nakazali od nich rozpocząć dzieło zniszczenia. Oszczędzono na razie domy prywatne, choć w zamyśle było zrównanie Waszyngtonu z ziemią. Zaczęto więc od podpalania największych symboli miasta, takich jak Kapitol, dom prezydenta, zwany rezydencją prezydencką (presidential mansion), a także budynków departamentów armii, skarbu i arsenału. Kontradmirał Cockburn osobiście podpalił dom prezydenta. Było to dla niego bardzo ważne i stanowiło wielki powód do dumy. Dlatego też po powrocie do Wielkiej Brytanii, chełpiąc się zniszczeniem Waszyngtonu, polecił namalować swój portret na tle tego płonącego miasta ${ }^{36}$.

Brytyjscy żołnierze także pałali żądzą zemsty. Nic dziwnego, że dawali upust swojej nienawiści za przegraną wojnę z Amerykanami o ich niepodległość, a więc oderwanie się od Imperium Brytyjskiego, jak i za niedawne spalenie stolicy Kanady. Naoczny świadek tamtych wydarzeń, brytyjski oficer George Robert Gleig pisał: „Kiedy grupa żołnierzy brytyjskich, oddelegowana do zniszczenia Białego Domu, weszła do jadalni, zastała stół nakryty dla czterdziestu osób. Zasiedli więc do uczty i nasyciwszy swe apetyty, nie żałując wina, zakończyli biesiadę podłożeniem ognia pod dom, który ich ugościl" ${ }^{37}$.

Nasuwa się pytanie, dlaczego czekała uczta na tyle osób przygotowana w domu prezydenta. Otóż istnieją dwa wytłumaczenia. Pierwsze, dość propagandowe, głosi, że J. Madison mimo tego, co zobaczył pod Bladensburgiem, ufał, że stolicę uda się ocalić. Dlatego też przygotował ucztę. „Wprosił” się na nią jednak najeźdźca, brytyjski kpt. William Blanshard. Drugą wersję podałam wyżej - uczta miała wprowadzić Brytyjczyków w błąd, sugerując, że prezydent i członkowie rządu są nadal w posiadłości. Ta jest bardziej prawdopodobna.

\footnotetext{
${ }^{34}$ Opis: https://www.whitehousehistory.org/the-burning-of-washington (dostęp: 23 XI 2020).

35 Szacuje się, że 90 procent ludzi uciekło z Waszyngtonu - https://www.whitehousehistory.org/ the-burning-of-washington (dostęp: 23 XI 2020).

${ }^{36}$ Portret ten znajduje się w Muzeum Morskim (National Maritime Museum) w Greenwich - $c f$ : R. KŁosowicz, op. cit., s. 184, który podał inną lokalizację obrazu.

37 Cit. per: ibidem, s. 184.
} 
Waszyngton płonął. Płomienie wzbijały się w niebo do późna w nocy. Podpalaniem zajęli się bowiem saperzy i minerzy (sapers and miners) z Korpusu Królewskich Inżynierów (Corps of Royal Engineers) dowodzonego przez kapitana Blansharda. Znali się na rzeczy i metodycznie realizowali dzieło zniszczenia. Ich działania były przemyślane. Najpierw podpalili najbardziej reprezentacyjny budynek, jakim był Kapitol. Zaczęli od skrzydła południowego, w którym obradowała Izba Reprezentantów, a następnie przeszli do północnego, będącego miejscem obrad Senatu ${ }^{38}$. Zanim jednak podpalili budynek, dokładnie go splądrowali. Wiedzieli, że funkcjonował w nim także Sąd Najwyższy i mieściła się Biblioteka Kongresu. Zniszczeniu za jednym zamachem miały ulec wszystkie trzy filary władzy - wraz z miejscem przechowywania najważniejszych dokumentów państwowych i zbiorów książkowych. Plądrującym Brytyjczykom wpadła w ręce księga dotycząca rachunków państwowych za rok 1810 („An account of the receipts and expenditures of the United States for the year 1810”) ${ }^{39}$. Księgozbiorem natomiast się nie przejmowali. Ogień pochłonął ponad 30 tys. tomów znajdujących się w Bibliotece Kongresu. Odbudował ją były prezydent T. Jefferson, przekazując na ten cel własny księgozbiór. Szacowanie strat pożaru Kapitolu zostało określone na 787 163,28 dolarów, z czego 457 388,36 dolarów przypadło na skrzydło północne i budynek główny, a 329 774,92 dolarów na skrzydło południowe ${ }^{40}$.

Po spaleniu Kapitolu Brytyjczycy ruszyli ku rezydencji prezydenta. Udali się zatem na północny zachód w górę Pennsylvania Avenue. O uczcie już pisałam, więc dodam tylko, że do ognia dolano paliwa, które miało zapewnić całkowite spłonięcie budynku. Warto nadmienić, że zanim żołnierze brytyjscy zaczęli plądrować dom prezydenta, pierwsi zrobili to lokalni złodzieje. Anglicy ujrzeli otwarte szuflady i porozrzucane rzeczy. Czego nie zabrali rabusie, spłonęło od ognia podłożonego przez Brytyjczyków.

Tej pamiętnej nocy 24 sierpnia paliły się przede wszystkim Kapitol i dom prezydenta. Około północy zmęczeni Brytyjczycy postanowili następnego dnia kontynuować dzieło zniszczenia ${ }^{41}$. Rankiem 25 sierpnia kontradmirał Cockburn wszedł do wydawnictwa gazety „National Intelligencer”, aby tam pod-

38 Vide: https://www.senate.gov/artandhistory/history/common/generic/August_Burning Washington.htm (dostęp: 23 XI 2020).

39 Vide: https://en.wikipedia.org/wiki/Burning_of_Washington (dostęp: 23 XI 2020).

40 Dane za: https://en.wikipedia.org/wiki/Burning_of_Washington (dostęp: 23 XI 2020).

${ }^{41}$ Brytyjczycy byli naprawdę wycieńczeni. $Z$ powodu upału 18 żołnierzy zmarło podczas marszu z Bladensburga do Waszyngtonu. Byli zmęczeni, spragnieni i głodni. 
łożyć ogień. Była to osobista zemsta za to, że gazeta określiła go mianem the Ruffian, czyli 'brutal'. Nie spalił jednak budynku, ale nakazał rozebrać go cegła po cegle. Dlaczego? Otóż ubłagały go kobiety, które powiedziały, że pożar spowoduje również spalenie się ich domów prywatnych. Pamiętał jednak o tym, aby zniszczyć wszystkie maszyny drukarskie, aby „łotry nie miały dalszych możliwości szkalowania mojego imienia”².

Także rano Brytyjczycy odszukali budynek Departamentu Skarbu Stanów Zjednoczonych. Niewątpliwie szukali pieniędzy. Zawiedli się, z tym większą ochotą spalili i ten budynek. Podpalili kolejne obiekty federalne, w tym Departamentu Wojny i Skarbu Państwa (United States Treasury). Na szczęście prawie wszystkie dokumenty z Departamentu Wojny zostały wcześniej wywiezione. Udało się uniknąć spalenia gmachu Urzędu Patentowego. Stało się to dzięki wstawiennictwu Williama Thorntona, który był architektem Kapitolu, a w dodatku umiejętnie przekonywał, że wewnątrz budynku Urzędu Patentowego jest wyłącznie własność prywatna. Był to jedyny budynek państwowy, który pozostał nienaruszony przez Brytyjczyków. Oszczędzono także budynki przeznaczone na koszary piechoty morskiej, gdyż uznano je za mieszkalne, a także dom komendanta, który jednak miejscowa ludność dokładnie obrabowała. Po południu 25 sierpnia gen. Ross wysłał 200 żołnierzy, aby zabezpieczyli fort na Greenleaf's Point. Wiedział, że pozostało tam 150 beczek prochu. Brytyjczycy wrzucali beczki do studni, jednak wówczas proch uległ samozapłonowi. W efekcie zginęło 31 brytyjskich żołnierzy, a sześciu odniosło rany ${ }^{43}$.

Waszyngton płonął. Dzieła zniszczenia dokonywali zarówno żołnierze brytyjscy, jak i niekiedy sami Amerykanie. Taka sytuacja zdarzyła się w stoczni, którą rozkazał spalić amerykański kapitan, aby uniemożliwić Brytyjczykom korzystanie z niej. Polecił wszakże pozostawić domy prywatne na terenie stoczni, w tym swój. Były one niepilnowane, co wykorzystali miejscowi, ograbiając te domy niemal do gołej cegły. Świadczy o tym zapis: „nie zostawiono żadnego przedmiotu, począwszy od piwnicy po strych, zabrano nawet armaturę i klamki od drzwi”44.

${ }^{42}$ Cit. per: https://en.wikipedia.org/wiki/Burning_of_Washington\#cite_note-FOOTNOTEFredriksen2001116-29 (dostęp: 23 XI 2020).

43 Dane za: https://en.wikipedia.org/wiki/Burning_of_Washington (dostęp: 23 XI 2020).

${ }^{44}$ N. TAYLOR, National Register of Historic Places Inventory - Nomination Form: https:// npgallery.nps.gov/GetAsset?assetID=ae686c5f-d8ff-42d1-9cfa-6ec837b5682f (dostęp: 23 XI 2020). 


\section{Burza, która uratowała Waszyngton}

Tego samego dnia (25 sierpnia) przyszła nagła burza. Obfite opady deszczu ugasiły pożary, ale dopełniły dzieła zniszczenia. Nadpalone mury pękały i osuwały się na ziemię. Burzę poprzedziło tornado, które przetoczyło się przez środek miasta. To, co zostało uratowane przed ogniem, zostało zniszczone przez wiatr. Gwałtowne jego podmuchy na Constitution Avenue uniosły w górę dwa działa i z ogromną siłą rzuciły je na ulicę. W wyniku tego zdarzenia życie straciło kilku brytyjskich żołnierzy i kilku amerykańskich cywilów.

Pojawienie się tornada było tak nieoczekiwane, że uznawano je za znak Opatrzności, który wypędził Anglików z miasta. Tornado jest bowiem niezwykle rzadkim zjawiskiem dla tej części kraju. W ciągu 204 lat odnotowano zaledwie siedem takich pogodowych incydentów. Amerykanie uważają, że ta ogromna burza z deszczem uratowała Waszyngton, zmuszając brytyjskich żołnierzy do opuszczenia miasta. Określają to jako „Storm that Saved Washington” („Burza, która uratowała Waszyngton”) ${ }^{45}$. Nieraz piszą, że stało się to dzięki tornadu ${ }^{46}$.

Nasuwa się pytanie, do jakiego stopnia bezsilne były wojska amerykańskie, skoro nie umiały przewidzieć ruchów przeciwnika, który systematycznie, krok po kroku posuwał się dalej, aby zrealizować cel, jakim było zrównanie z ziemią miasta symbolizującego nowe państwo. Amerykanie unikają tego tematu. Opis niszczenia miasta jest poruszający, ale ukazuje bezlitośnie indolencję głównodowodzących, nie pierwszą i nie jedyną w czasie wojny z Brytyjczykami. Wielokrotnie historiografia amerykańska woli odwoływać się do pomocy Opatrzności, a także tworzyć legendy, jak chociażby tę o uratowaniu obrazu G. Washingtona przez Dolley Madison, niż przyznać się do popełnianych wówczas błędów. Historia płonącego Waszyngtonu jest ładnie opisywana, ukazuje pałających żądzą zemsty Anglików, a także wskazuje na kilku amerykańskich bohaterów. Prawda jest jednak bezlitosna i ukazuje szereg zaniechań ze strony zarówno głównodowodzącego Armią Kontynentalną, jak i dowódców odpowiedzialnych za powierzone im tereny działań. Burza czy tornado, a więc siły natury, czy jak kto woli

${ }^{45}$ https://www.warhistoryonline.com/history/the-tornado-that-saved-washington.html (dostęp: 10 XI 2020).

46 https://www.smithsonianmag.com/science-nature/the-tornado-that-saved-washington-33901211/ (dostęp: 10 XI 2020). 
Opatrzność pokonały wojska brytyjskie, a nie amerykańska armia. Legenda i opowieść ta jest piękna, acz tuszująca prawdę historyczną.

Faktycznie po burzy brytyjscy żołnierze się wycofali. Wieczorem 25 sierpnia gen. Ross zarządził odwrót. Ruszyli w kierunku oddalonego o 64 kilometry Baltimore. Waszyngton był w rękach angielskich jedynie przez 26 godzin. Burza i tornado zapewne przyspieszyły opuszczenie miasta. Brytyjczycy nie zamierzali w nim zostawać. Ich celem było zniszczenie symbolu amerykańskiego państwa i załamanie wiary obywateli. Chodziło o unicestwienie symbolu, a nie miasta samego w sobie. Cel ten osiągnęli. Straty były ogromne. Zniszczenie Kapitolu, w tym Senatu i Izby Reprezentantów, Biblioteki, Arsenału, Stoczni, Skarbu, Urzędu Wojennego, rezydencji prezydenta, mostu nad Potomakiem, fregaty i slupu oszacowano na 365 tys. funtów.

Prezydent J. Madison wrócił do ruin miasta jeszcze przed 1 września. Nadzwyczajna sesja Kongresu została zwołana na 19 września. Amerykanie, wbrew angielskim planom, nie załamali się. Przeciwnie, dodało im to sił. Po pierwsze, podjęto decyzję o natychmiastowej odbudowie stolicy. Po drugie, ani prezydent, ani senatorowie i kongresmeni nie przenieśli się do innego miasta na czas odbudowy, tylko wykorzystali ocalały z pożaru budynek patentowy. Wkrótce zamieszkali w specjalnie dla nich wzniesionym dwupiętrowym budynku z czerwonej cegły. Od 1819 r. zaczęli obradować w odbudowywanym Kapitolu, a w ceglanym budynku mieszkali do 1825 r. Potocznie nazywano go Old Brick Capitol. Siedzibą prezydenta został początkowo dawny dom Madisonów przy ulicy „F”, a później budynek zwany Octagon House, co było odniesieniem do 8 lat urzędowania ${ }^{47}$. Remont rezydencji prezydenta rozpoczęto w $1815 \mathrm{r}$. Dwa lata później kolejny prezydent, którym był James Monroe, został zaprzysiężony w dawnym, choć nadal jeszcze nieodbudowanym gmachu. Potocznie zaczęto nazywać go Białym Domem (White House) ze względu na użycie białej farby, którą zamalowano nadpalenia, i białego wapienia do odbudowy. Po trzecie, Amerykanie doczekali się hymnu państwowego ${ }^{48}$. Skomponował go Francis Scott Key, który uwięziony przez Brytyjczyków na pokładzie okrętu wojennego obserwował przebieg bitwy o Fort McHenry i łopoczącą amerykańską flagę. Bitwa zaczęła się niemal natychmiast po dojściu Brytyjczyków do Baltimore po opuszczeniu spalonego Waszyngtonu.

\footnotetext{
47 Vide: J.A. DaszyŃsKa, Kryzysy i kompromisy..., s. 194-195.

48 Vide: ibidem, s. 93-94.
} 
Symbol amerykańskiego państwa, jakim było nowe miasto, wybudowane od podstaw i niemal od podstaw odbudowane, zaczęło się powoli rozrastać i do dziś pełni funkcję stolicy Stanów Zjednoczonych. To urzeczywistnienie mitu o powstaniu feniksa z popiołów, jak odbudowę Waszyngtonu określił Thomas Law, zagraniczny podróżny ${ }^{49}$.

\section{BIBLIOGRAFIA}

\section{Źródła}

The Residence Act of 1790. An Act for Establishing the Temporary and Permanent Seat of the Government of the United States, www.ushistory.org/presidentshouse/history/act1790. htm (dostęp: 10 XI 2020).

Statement on the subject of The District of Columbia Fair and Equal Voting Rights Act, American Bar Association, September 14, 2006 (Retrieved August 10, 2011).

\section{Opracowania}

Bowling K.R., The Creation of Washington, D.C.: The Idea and Location of the American Capital, Fairfax, Va. 1991.

Daszyńska J.A., Kryzysy i kompromisy w Stanach Zjednoczonych Ameryki czasów Ojców Zatożycieli, Łódź 2018.

Daszyńska J.A., Narodziny tradycji. Symbole amerykańskiej demokracji, Łódź 2010.

The District of Columbia. The Seat of Government, by B.A. Weisberger, New York 1969.

Fergus M., Bordewich F.M., Washington: The Making of the American Capital, New York 2008. Flexner J.T., George Washington and the New Nation (1783-1793), Boston-Toronto 1970. Jones M.A., Historia USA, przekł. P. Kurowski, P. Ostaszewski, Gdańsk 2002. Kłosowicz R., Wojna amerykańsko-brytyjska 1812-1814, Kraków 2003.

\section{Netografia}

James Madison, War Message, 1 VI 1812, https://loveman.sdsu.edu/docs/1812SpecialMessagetoCongresswarmessage.pdf (dostęp: 10 XI 2020).

49 Vide: https://www.battlefields.org/learn/articles/burning-washington-dc (dostęp: 24 XI 2020). 
https://www.whitehousehistory.org/the-burning-of-washington (Richard Rush o Waszyngtonie) (dostęp: 10 XI 2020).

https://www.whitehousehistory.org/the-burning-of-washington (Augustus John Foster o Waszyngtonie) (dostęp: 10 XI 2020).

https://www.nps.gov/stsp/learn/historyculture/battle-of-bladensburg.htm (James Monroe o zagrożeniu stolicy) (dostęp: 10 XI 2020).

Taylor N., National Register of Historic Places Inventory - Nomination Form, https://npgallery.nps.gov/GetAsset?assetID=ae686c5f-d8ff-42d1-9cfa-6ec837b5682f (dewastacja Waszyngtonu) (dostęp: 10 XI 2020).

https://history.house.gov/Institution/Firsts-Milestones/First-Meetings/ (pierwsze posiedzenie Kongresu w Waszyngtonie) (dostęp: 10 XI 2020).

https://matthewbgilmore.wordpress.com/district-of-columbia-population-history/ (mieszkańcy Waszyngtonu, dane liczbowe) (dostęp: 10 XI 2020).

https://www.battlefields.org/learn/biographies/george-pr\%C3\%A9vost (Sir George Prevost) (dostęp: 10 XI 2020).

https://www.battlefields.org/learn/biographies/alexander-cochrane (Alexander Cochrane) (dostęp: 10 XI 2020).

https://www.nps.gov/people/george-cockburn.htm (George Cockburn) (dostęp: $10 \mathrm{XI}$ 2020).

https://www.nps.gov/articles/bladensburg-races.htm (siły wojsk pod Bladensburgiem) (dostęp: 10 XI 2020).

https://www.battlefields.org/learn/war-1812/battles/bladensburg (siły wojsk pod Bladensburgiem) (dostęp: 10 XI 2020).

https://www.nps.gov/articles/bladensburg-races.htm (bitwa pod Bladensburgiem) (dostęp: 10 XI 2020).

https://www.nps.gov/stsp/learn/historyculture/battle-of-bladensburg.htm (bitwa pod Bladensburgiem) (dostęp: 10 XI 2020).

https://www.whitehousehistory.org/the-burning-of-washington (spalenie Waszyngtonu) (dostęp: 10 XI 2020).

https://www.senate.gov/artandhistory/history/common/generic/August_Burning_Washington.htm (spalenie budynku Kongresu) (dostęp: 10 XI 2020).

https://www.senate.gov/artandhistory/history/common/generic/August_Burning_Washington.htm (zniszczenie maszyn drukarskich) (dostęp: 10 XI 2020).

https://www.smithsonianmag.com/science-nature/the-tornado-that-saved-washington-33901211/ (tornado, które uratowało Waszyngton) (dostęp: 10 XI 2020).

https://www.warhistoryonline.com/history/the-tornado-that-saved-washington.html (burza, która uratowała Waszyngton) (dostęp: 10 XI 2020).

https://www.battlefields.org/learn/articles/burning-washington-dc (odbudowa Waszyngtonu) (dostęp: 10 XI 2020). 


\section{Jolanta A. Daszyńska}

\section{FACTS AND LEGENDS ABOUT THE BURNING OF WASHINGTON, D.C. IN 1814}

Summary. Federal City as Washington, D.C. was called was a symbol for Americans. It was both the capital and a symbol of new federal power. It was indicated on map in 1790 and within ten years be ready to start. In retaliation for the Americans' recent burning of the Canadian capital at York (Toronto), British troops descended on Washington, D.C. On August 24, 1814 they entered the city. At night they torched the Capitol, the President's Mansion and nearly every other public buildings. Washington, D.C. was burning for 26 hours. Suddenly a huge storm and an accompanying tornado, although still destructive, actually helped save the American capital from further occupation and destruction by British troops. The storm became known as „Storm that Saved Washington".

Keywords: Washington, D.C., burning of Washington, war of 1812, battle of Bladensburg, George Cockburn 